\title{
Pemaknaan Etika Jurnalisme Warga oleh Jurnalis Warga NETCJ di Wilayah Solo
}

\author{
Cindy Mutia Annur dan Pandan Yudhapramesti \\ PT. Kata Data \\ Email: cindymutiaannur14@gmail.com
}

\begin{abstract}
The character of citizen journalism which is open and free to do by anyone, making it a challenge for the perpetrators. Although there are no official written principles or rules regarding the ethics of citizen journalism, at least citizen journalists can interpret the current journalism ethics as a guide. Based on the assessment of the NETCJ editorial staff, the Solo area is the most numerous and actively sends citizen journalism coverage. Therefore, this study aimed to explore the meaning of ethics of citizen journalism by journalists from NETCJ citizens in the Solo area. Through qualitative research methods, phenomenological approaches, and symbolic interaction theories, this study aimed to explore their motives, experiences, and agreements in applying the ethics of citizen journalism. The results showed that the ethics of citizen journalism were interpreted as aspects of morality and quality. The aspect of morality related to courtesy and ethics, while the quality aspect related to the quality of content which judged according to rules in journalism.
\end{abstract}

Keywords: ethics, citizen journalism, citizen journalist, phenomenology, symbolic interaction

\begin{abstract}
Abstrak
Sifat jurnalisme warga yang terbuka dan bebas dilakukan oleh siapa saja, menjadikannya tantangan tersendiri bagi pelakunya. Meski belum ada kumpulan prinsip atau aturan tertulis secara resmi mengenai etika jurnalisme warga, setidaknya jurnalis warga dapat memaknai etika jurnalisme yang berlaku saat ini sebagai pedomannya. Penelitian ini bertujuan untuk menggali pemaknaan etika jurnalisme warga oleh jurnalis warga $N E T C J$ di wilayah Solo, karena wilayah Solo merupakan wilayah paling banyak dan aktif mengirimkan liputan jurnalisme warga. Melalui metode penelitian kualitatif, pendekatan fenomenologi, serta teori interaksi simbolik, penelitian ini bertujuan untuk menggali motif, pengalaman, dan kesepakatan mereka dalam menerapkan etika jurnalisme warga. Hasil penelitian menunjukkan bahwa etika jurnalisme warga dimaknai sebagai aspek moralitas dan kualitas. Aspek moralitas berkaitan dengan sopan santun dan etika, sedangkan aspek kualitas berkaitan dengan mutu konten yang dinilai berdasarkan aturan dalam jurnalistik.
\end{abstract}

Kata kunci: etika, fenomenologi, interaksi simbolik, jurnalis warga, jurnalisme warga

\section{PENDAHULUAN}

Dewasa ini semakin banyak warga yang terjun menjadi jurnalis warga di media massa. Fenomena ini muncul seiring dengan munculnya perkembangan teknologi internet yang memungkinkan siapa saja mengakses dan memproduksi informasi. Setiap orang bisa mengisi ruang jurnalisme warga. Dalam beberapa hal, media profesional dapat terbantu untuk mendapatkan informasi berkualitas dari segala penjuru negeri selama informasi yang disampaikan warga memenuhi unsur nilai berita faktual dan penting serta menyangkut kepentingan banyak orang (Sukartik, 2016).

Selain meningkatkan jurnalisme itu sendiri, argumen normatif yang mendukung

Korespondensi: Cindy Mutia Annur, S.Sos, PT Katadata Indonesia, Permata Senayan Blok D No. 31, Jl. Tentara Pelajar, Jakarta, Indonesia, 12210, email: cindymutiaannur14@gmail.com 
jurnalisme warga bertumpu pada harapan bahwa jurnalisme akan memberkahi 'para produser warga' dengan rasa hormat yang baru, berdasarkan pada pengakuan publik atas suara-suara warga negara yang secara luas dianggap tidak hadir dalam beberapa dekade terakhir (Markham, 2009). Jurnalisme sendiri sejak awal diposisikan tidak lepas dari keterlibatan warga (Eddyono, HT, \& Irawanto, 2019). Warga dapat berperan sebagai khalayak maupun penggali, pengelola, serta penyampai informasi.

Kendati memperoleh tempat khusus dalam jurnalisme, tentu tidak semua jurnalis warga yang terdiri dari 'warga biasa' paham dan dapat memaknai etika jurnalisme layaknya wartawan profesional. Sebagai contoh, dalam program NET Citizen Journalist (NETCJ), redaksi masih menemukan ada anggota jurnalis warganya yang tidak beretika dengan baik saat proses meliput berita. Mereka diduga menyalahi statusnya sebagai jurnalis warga di NETCJ dengan menerima amplop dan mengaku sebagai wartawan.

Menurut Nugraha (2012: 18-19), citizen journalism adalah warga biasa yang tidak terlatih sebagai wartawan profesional, namun dengan peralatan teknologi informasi yang dimilikinya bisa menjadi saksi mata atau sebuah peristiwa yang terjadi di sekitarnya, meliput, mencatat, mengumpulkan, menulis, dan menyiarkannya di media online karena memiliki semangat berbagi dengan pembaca lainnya. Sifat jurnalisme warga yang terbuka dan bebas dilakukan oleh siapa saja, membuatnya menjadi tantangan tersendiri bagi pelakunya. Seorang jurnalis warga tetap harus mempertanggungjawabkan konten berita yang telah dibuatnya dengan cara yang profesional. Oleh karena itu, jurnalisme warga juga harus berpedoman pada etika jurnalisme yang berlaku.

Etika jurnalisme merupakan sekumpulan prinsip moral yang merefleksikan peraturanperaturan. Ia bisa dinyatakan secara tertulis atau tidak, dan tentu saja, etikanya dipatuhi segala pelaku dan perilaku jurnalisme (Santana, 2017: 2017). Jurnalisme warga juga termasuk bagian dari perilaku jurnalisme. Oleh karena itu, etika jurnalisme warga juga penting diterapkan oleh jurnalis warga.

Dalam konteks etika jurnalisme warga, etika dianggap sebagai nilai atau norma yang digunakan sebagai pegangan bagi mereka saat melakukan kegiatan jurnalistik. Hingga saat ini belum ada kumpulan prinsip atau aturan tertulis yang dibuat secara resmi mengenai etika jurnalisme warga, seperti Kode Etik Jurnalistik ataupun Undang-Undang Pers yang dibuat khusus untuk wartawan profesional. Namun setidaknya, jurnalis warga dapat memaknai etika jurnalisme yang berlaku saat ini sebagai pedomannya.

Etika jurnalisme warga memang seharusnya tidak hanya soal moralitas saja, tetapi juga soal kualitas dan pertanggungjawaban berita yang dibuat. Untuk itu, jurnalis warga juga harus menghasilkan berita yang akurat, berimbang, dan sesuai kaidah jurnalistik. Tentunya, mereka juga harus menempuh cara yang profesional dalam membuat berita. Misalnya, menunjukkan identitas diri kepada narasumber, tidak menerima suap, membuat berita yang faktual dan dapat terbukti kebenarannya, seperti yang dipaparkan dalam Kode Etik Jurnalistik dan UndangUndang Pers.

Belajar dari pengalaman media jurnalisme warga di Korea Selatan, agar dapat membangun kredibilitas dan keobjektivan dalam jurnalisme kontemporer, jurnalisme warga perlu mengembangkan pendidikan dan pelatihan untuk jurnalis warga; membangun kolaborasi antara jurnalis profesional dan warga; serta, dalam melaksanakan tugasnya, jurnalis harus didasari oleh sembilan elemen jurnalisme yang dinyatakan oleh tokoh jurnalis dan penulis terkemuka Bill Kovach dan Tom Rossenstiel. Ketiga cara ini diharapkan dapat membangun idealisme media sebagai kontrol sosial dan sarana pendidikan masyarakat (Widodo, 2017).

Sejak Mei 2013, NETCJ menggunakan wadah media online, yakni netcj.co.id, yang 
memungkinkan masyarakat untuk mencari, menonton, dan berbagi informasi berita lewat video hasil karya sendiri. Kontennya dapat berupa berita langsung (straight news) dan juga berita khas (feature). Video yang menarik dan memiliki nilai berita tinggi, biasanya ditayangkan di program-program berita NET. Sebagai imbalannya, para jurnalis warga akan mendapatkan honorarium dari pihak NETCJ sesuai kategori beritanya.

Menurut pengelola $N E T C J$, jumlah anggota yang terdaftar di situs $N E T C J$ sudah mencapai 500.000 orang. Jurnalis warga tersebut tersebar hampir di setiap daerah di Indonesia, bahkan mencapai 75 negara dari seluruh dunia. Tiap daerah memiliki perwakilan jurnalis warganya masing-masing yang terlibat aktif mengirimkan video berita untuk NETCJ.

Besarnya jumlah anggota NETCJ, menjadi salah satu bukti bahwa antusiasme para jurnalis warga di program tersebut cukup besar. Inilah yang menjadi salah satu alasan peneliti memilih program NETCJ dalam penelitian ini. Jurnalis warga $N E T C J$ pun mengakui keunggulan program ini dibandingkan program jurnalisme warga lainnya.

Berdasarkan data pra-riset peneliti pada 5 - 11 Maret 2018, 14 dari 15 jurnalis warga NETCJ mengakui bahwa interaksi antara redaksi $N E T C J$ dengan para jurnalis warganya terjalin dengan baik. Di antaranya, redaksi cukup aktif merangkul anggotanya lewat grup Facebook maupun sosialisasi informasi di Instagram dan Twitter, memberikan evaluasi atau masukan terhadap hasil karya jurnalis warganya, mengajak untuk mengikuti kontes video NETCJ yang diadakan dalam menyambut moment tertentu, dan lain sebagainya.

Pengelola NETCJ mengatakan, daerah yang memiliki pengirim video NETCJ terbanyak dan teraktif terdapat di Jawa Tengah, salah satunya di wilayah Solo. Wilayah ini memiliki jurnalis warga yang paling banyak dan aktif mengirimkan liputan $N E T C J$ secara keseluruhan di wilayah Indonesia. Salah satu jurnalis warga asal Solo yang tergolong aktif di NETCJ misalnya dapat mengirimkan video untuk NETCJ sebanyak 4 sampai 5 video dalam satu minggu secara rutin. Hingga Maret 2018, tercatat total karyanya yang telah dipublikasikan oleh NETCJ mencapai 455 video sejak Juni 2014.

Dalam penelitian ini peneliti berkesempatan untuk bergabung di grup Whatsapp CJ Soloraya, yakni komunitas jurnalis warga di wilayah Solo. Dinamakan Soloraya, karena anggotanya berasal dari wilayah Solo yang meliputi Solo, Sukoharjo, Karanganyar, Klaten, Boyolali, Sragen, dan Wonogiri. Menurut admin dari grup tersebut, total jurnalis warga Solo yang aktif mengirim liputan yakni sekitar 15 orang dari 29 anggota yang terdaftar di grup tersebut.

Melalui pengamatan peneliti, hampir setiap hari mereka aktif berdiskusi seputar informasi liputan, honorarium, maupun sekedar bergurau. Beberapa di antara mereka bahkan sering berbagi informasi mengenai undangan liputan yang ditujukan kepada rekan media. Lewat grup ini pula, mereka saling menyemangati satu sama lain untuk membuat liputan jurnalisme warga, salah satunya dikirimkan ke NETCJ.

Melihat keaktifan para jurnalis warga di wilayah Solo dan juga pernyataan langsung dari redaksi NETCJ, peneliti tertarik untuk meneliti tentang pemaknaan etika jurnalisme warga oleh jurnalis warga NETCJ di wilayah Solo. Dalam wawancara pra-riset peneliti, 3 informan yang berasal dari wilayah Solo mengaku tahu tentang etika jurnalisme. Akan tetapi, apakah mereka dapat memaknai "etika jurnalisme" itu sendiri secara langsung terutama saat di lapangan?

Pada setiap tindakan individu, terdapat motif menjadi orientasi dari tindakannya. Sebuah penelitian tentang pemaknaan profesi bagi jurnalis perempuan di Kota Ambon mengidentifikasi dua jenis motif yang melandasi tindakan jurnalis perempuan, motif sebab dan motif tujuan. Motif sebab menjadi jurnalis antara lain karena cita-cita, pengaruh tokoh idola, menyukai dunia tulis menulis, menyukai tantangan, serta kebutuhan untuk aktualisasi diri. Sementara motif 
tujuan menjadi jurnalis antara lain karena tujuan untuk terus belajar, memperoleh manfaat dari aktivitas jurnalisme serta menjalankan idealisme (Dan \& Iii, 2017).

Jurnalisme warga memang bukan sebuah profesi. Namun kesadaran akan nilai penting aktivitas jurnalisme baik yang dijalankan oleh warga maupun jurnalis profesional, turut melandasi pemahaman dan tindakan yang dilakukan oleh jurnalis warga maupun jurnalis profesional. Dalam penelitian tentang "Makna Jurnalisme Warga bagi Jurnalis Warga NET CJ.co.id" Iqbal menyebutkan bahwa terdapat beberapa motif yang mendorong informan menjalankan aktivitas jurnalisme warga, yakni kepuasan dan pengembangan pribadi, serta motif yang mendasari tugas utama seorang jurnalis yaitu menyebarkan informasi dan membuat perubahan sosial dengan menghadirkan konten alternatif (Iqbal \& Sjafirah, 2019). Dalam penelitian ini disebutkan juga bahwa para informan menganggap jurnalisme warga merupakan aktivitas yang dapat melatih warga untuk belajar menjadi jurnalis profesional, namun melalui konten alternatif yang berbeda dari media arus utama.

Selaras dengan pengakuan informan pada penelitian Iqbal bahwa jurnalisme warga adalah sarana belajar menjadi jurnalis profesional, peneliti juga tertarik untuk mengetahui bagaimana para jurnalis warga di wilayah Solo menghadapi berbagai persoalan rutin tugas kejurnalistikan yang dihadapi oleh orang-orang biasa atau jurnalis warga, seperti proses untuk mendapatkan akses undangan liputan yang biasanya tidak mudah didapatkan oleh warga biasa. Dari fenomena tersebut, diharapkan peneliti dapat menggali lebih dalam mengenai pengalaman mereka dalam menerapkan etika jurnalisme warga.

Dalam penelitian ini, peneliti menggunakan metode kualitatif dengan pendekatan fenomenologi. Hal ini dikarenakan metode ini sangat tepat untuk diterapkan pada penelitian yang berkaitan dengan pemaknaan. Lewat metode ini, kita dapat mengetahui dunia dari sudut pandang orang yang mengalaminya secara langsung yang berkaitan dengan sifat-sifat alami pengalaman manusia, dan makna yang ditempelkan padanya.

Tradisi studi Fenomenologi menurut Cresswell (2010) adalah: "Whereas a biography reports the life of a single individual, a phenomenological study describes the meaning of the live experiences for several individuals about a concept or the phenomenon". Dengan demikian, studi dengan pendekatan fenomenologi berupaya untuk menjelaskan makna pengalaman hidup sejumlah orang tentang suatu konsep atau gejala, termasuk di dalamnya konsep diri atau pandangan hidup mereka sendiri.

Fenomenologi sebagai metode penelitian tidak menggunakan hipotesis dalam prosesnya, walaupun fenomenologi bisa jadi menghasilkan sebuah hipotesis untuk diuji lebih lanjut. Selain itu, fenomenologi tidak diawali dan tidak bertujuan untuk menguji teori. Jadi pada praktiknya, fenomenologi cenderung untuk menggunakan metode observasi, wawancara mendalam (kualitatif), dan analisis dokumen dengan metode hermeneutik (Kuswarno, 2009: 36).

Dalam mengupas penelitian ini, peneliti menggunakan Teori Fenomenologi Alfred Schutz. Inti pemikiran Schutz adalah bagaimana memahami tindakan sosial melalui penafsiran. Proses penafsiran ini dapat digunakan untuk memperjelas atau memeriksa makna yang sesungguhnya, sehingga dapat memberikan konsep kepekaan yang implisit.

Penelitian ini mengkaji tentang bagaimana para jurnalis warga di wilayah Solo memaknai etika jurnalisme warga saat melakukan liputan di lapangan. Maka dari itu, peneliti ingin mengetahui motif mereka menerapkan etika jurnalisme warga, pengalaman saat menerapkan etika jurnalisme warga di lapangan, dan kesepakatan mereka mengenai etika jurnalisme warga.

Berbagai pertimbangan tersebut dirumuskan dalam penelitian ini menjadi, "Bagaimana pemaknaan etika jurnalisme warga oleh jurnalis warga NETCJ di wilayah Solo?" Rumusan ini diidentifikasi lebih lanjut menjadi apa motif jurnalis warga $N E T C J$ di wilayah Solo dalam 
DOI: $10.24198 /$ jkj.v3i2.22167

menerapkan etika jurnalisme warga; seperti apa pengalaman jurnalis warga NETCJ di wilayah Solo dalam menerapkan etika jurnalisme warga; bagaimana kesepakatan jurnalis warga NETCJ di wilayah Solo mengenai etika jurnalisme warga?

\section{METODE}

Dalam sebuah penelitian, dibutuhkan pendekatan terhadap masalah yang ingin diteliti. Pendekatan itu menggunakan langkah-langkah dan teori yang ada, sehingga perlu adanya metode penelitian. Mulyana (2010) menjelaskan, metodologi adalah proses, prinsip, dan prosedur yang digunakan untuk mendekati problem dan mencari jawaban. Dengan ungkapan lain, metodologi adalah suatu pendekatan umum untuk mengkaji topik penelitian.

Metodologi merupakan rentang, dari yang sangat kuantitatif (objektif) hingga yang sangat kualitatif (subjektif). Seperti juga teori, metodologi diukur berdasarkan kemanfaatannya dan tidak bisa dinilai apakah suatu metode benar atau salah. Menurut Mulyana, metode penelitian kualitatif tidak mengandalkan bukti berdasarkan logika matematis, prinsip angka, atau metode statistik, melainkan menganalisis tindakan sosial, seperti pembicaraan yang sebenarnya dan bahasa isyarat.

Metode penelitian kualitatif digambarkan seperti orang yang hendak piknik: ia baru tahu tempat yang akan dituju tapi belum tahu pasti apa yang ada di tempat itu. Artinya, walaupun dalam penelitian kualitatif masalah yang dikemukakan sudah ada, namun peneliti baru mengetahui informasi penelitian saat terjun ke lapangan. Metode ini berangkat dari pengamatan yang mendetail konkrit pada empirical social reality (Sugiono, 2007).

Dalam penelitian kualitatif, selalu menggunakan pola berpikir induktif untuk memahami suatu realitas. Peneliti yang terlibat langsung dalam situasi dan latar belakang fenomena yang diteliti, memusatkan perhatian pada suatu peristiwa sesuai dengan konteks penelitian. Thomas Lindlof (dalam Kuswarno, 2009) menyebutkan bahwa metode kualitatif dalam penelitian komunikasi dengan pendekatan fenomenologi, etnometodologi, interaksi simbolik, etnografi, dan studi budaya, sering disebut sebagai paradigma interpretif.

Menurut Mulyana (Mulyana, 2010), paradigma adalah suatu cara pandang untuk memahami kompleksitas dunia nyata. Paradigma menunjukkan apa yang penting, absah, dan masuk akal. Paradigma juga bersifat normatif, menunjukkan kepada praktisinya apa yang harus dilakukan tanpa perlu melakukan pertimbangan eksistensial atau epistemologis yang panjang. Sedangkan, Bogdan dan Biklen dalam Moleong (2017) menjelaskan, paradigma adalah kumpulan longgar dari sejumlah asumsi yang dipegang bersama, konsep atau proposisi yang mengarahkan cara berpikir dan penelitan.

Dalam penelitian ini, paradigma yang digunakan adalah paradigma konstruktivisme yang memandang realitas kehidupan sosial terbentuk dari hasil konstruksi. Oleh karena itu, fokus analisis dalam paradigma ini adalah menemukan bagaimana peristiwa atau realitas tersebut dikonstruksi dan dengan cara apa konstruksi itu dibentuk. Dalam studi komunikasi, paradigma ini sering kali disebut sebagai paradigma produksi dan pertukaran makna.

Peneliti ingin menggunakan metode penelitian kualitatif dalam penelitian ini, karena ingin mengungkap bagaimana pemaknaan etika jurnalisme warga oleh jurnalis warga NETCJ di wilayah Solo. Penelitian ini tidak tepat jika dilakukan dengan metode penelitian kuantitatif, karena tidak memenuhi karakteristik penelitian ini yang bersifat kualitatif. Di antaranya bersifat subjektif, deskriptif, teknik pengumpulan data lewat observasi, wawancara, studi dokumentasi, dan sebagainya.

Sumber-sumber rujukan yang dipergunakan dalam penelitian ini antara lain abstrak disertasi, tesis, skripsi, karya ilmiah, atau hasil fenomenologi yang telah dipublikasikan, buku- 
buku referensi, dokumen-dokumen yang relevan, jurnal-jurnal, dan tulisan lainnya (termasuk dari internet). Dalam penelitian ini, peneliti mencari data, teori, dan referensi lain yang berhubungan dengan etika, etika jurnalisme, jurnalisme warga, fenomenologi, dan interaksi simbolik.

\section{HASIL DAN PEMBAHASAN}

\section{Motif Menerapkan Etika Jurnalisme Warga}

Jurnalis warga NETCJ di wilayah Solo yang menjadi informan dalam penelitian ini memiliki motif atau alasan atas tindakan mereka dalam menerapkan etika jurnalisme warga. Peneliti merasa perlu untuk mencari tahu motif informan dalam menerapkan etika jurnalisme warga, karena hal tersebut secara sadar atau tidak sadar memengaruhi tindakannya saat liputan.

Para informan penelitian memiliki keputusannya masing-masing untuk menerapkan etika jurnalisme warga, yakni berdasarkan motif atau alasan atas tindakan mereka. Tindakan informan tersebut dipengaruhi oleh pengalaman dan interaksinya dengan orang lain. Pengaruh tindakan inilah yang kemudian membentuk makna terhadap aktivitas mereka dalam menerapkan etika jurnalisme warga.

Schutz memandang bahwa konsep tindakan (action) seseorang akan melihat ke depan pada masa yang akan datang (looking-forward into the future) untuk mewujudkan tujuan di masa datang yang telah ditetapkan (determinate). Selain itu, tindakan seseorang juga akan dipengaruhi masa lalu (pastness). Dengan demikian, tindakan memiliki elemen ke masa depan (futurity) dan ke masa lalu (pastness).

Untuk menggambarkan motif para informan dalam menerapkan etika jurnalisme warga, digunakan dua fase tindakan menurut Schutz, yakni fase tindakan because-motive (motif sebab) dan fase tindakan in-order-to motive (motif tujuan). Fase because-motive merupakan fase yang merujuk pada masa lalu. Sedangkan fase in-order-to motive merupakan fase tindakan yang merujuk pada masa yang akan datang. Berdasarkan hasil pengamatan dalam penelitian ini, kedua fase tersebut mempengaruhi tindakan para informan.

Tiga informan dalam penelitian menyatakan memilih untuk menerapkan etika jurnalisme warga berdasarkan pengalaman dan masa lalu mereka di lapangan. Salah seorang informan memiliki pengalaman bekerja di salah satu surat kabar Lokal. Meski bukan sebagai jurnalis, setidaknya ia tahu bagaimana kaidah-kaidah dalam jurnalistik yang dapat ia terapkan sebagai jurnalis warga. Pengalaman ini membuat dirinya ingin menerapkan etika jurnalisme warga agar menjaga kualitas beritanya, sehingga isinya bisa dipertanggungjawabkan. Ia selalu berusaha menerapkan etika jurnalisme yang sesuai dengan Kode Etik Jurnalistik. Sebelum menjadi jurnalis warga, informan ini sempat bekerja di salah satu surat kabar lokal Solo sebagai kartunis.

Menurut sang informan, informasi yang diperoleh jurnalis warga harus sesuai fakta dan sesuai dengan kaidah jurnalistik. Dengan menerapkan etika jurnalisme warga, ia dapat memproduksi liputan berita berkualitas, sehingga sering ditayangkan di NET dan diapresiasi oleh masyarakat setempat. Pengalaman serta masa lalu (because-motive) sang informan untuk senantiasa menjaga kualitas pada hasil liputannya tersebut, membuatnya berdisiplin menerapkan etika jurnalisme warga.

Informan ketiga dan kelima mengakui diri mereka dipengaruhi oleh pengalaman serta masa lalunya dalam pergaulan sehari-hari di masyarakat. Informan ketiga beranggapan bahwa etika jurnalisme warga merupakan bagian dari moralitas dan norma-norma yang harus diterapkan oleh jurnalis warga, seperti norma agama, norma sosial, dan norma kesopanan. Karenanya, ia menerapkan etika jurnalisme warga agar diterima di masyarakat dengan baik. Selama ia menerapkan etika jurnalisme warga, masyarakat setempat dan rekan-rekannya 
menyambut baik kehadirannya di lapangan. Dampaknya pun sangat dirasakan oleh informan ketiga ini, merasa disambut dengan baik saat liputan, terutama oleh narasumbernya. Oleh karena itu, sebagai jurnalis warga ia selalu menerapkan etika jurnalisme warga saat liputan.

Informan kelima juga mengakui menerapkan etika jurnalisme warga agar dapat menghasilkan liputan yang baik pula. Dengan berlandaskan moralitas, Kode Etik Jurnalistik, dan Undang-Undang Pers, ia dapat menerapkan etika jurnalisme warga. Sedangkan informan keempat mengatakan, dengan menerapkan etika yang baik dalam peliputan sebagai jurnalis warga, ia kerap mendapatkan informasi aktual dari beberapa narasumbernya. Hal ini tentu menguntungkan baginya, sehingga ia dapat membuat berbagai liputan dari sumber yang terpercaya. Hasil liputannya pun sering diapresiasi NET dan masyarakat setempat.

Selain motif sebab yang melandasi perilaku jurnalis untuk melakukan peliputan yang beretika selaku jurnalis warga, dua informan lainnya menerapkan etika jurnalisme warga berdasarkan motif tujuan atau tindakan yang merujuk pada masa yang akan datang. Mereka sama-sama menerapkan etika jurnalisme warga karena adanya tujuan yang ingin mereka capai di masa depan. Informan kedua mengaku menerapkan etika jurnalisme warga untuk menjaga nama baik dirinya sendiri dan media yang ia bawa, yakni NET. Meski tidak terikat dengan media apa pun, ia selalu berusaha menerapkan etika jurnalisme warga yang sesuai. Ia memandang etika jurnalisme warga sebagai bentuk moralitas yang harus dijaga sebagai seorang jurnalis warga. Menjaga nama baik diri dan media yang dibawa, dilakukan oleh informan dengan cara mengedepankan berita yang sesuai fakta, akurat, dan lengkap informasinya. Selain itu, ia juga selalu menjaga statusnya sebagai jurnalis warga, bersikap sopan santun, serta menjaga hubungan dengan narasumber maupun rekan-rekannya di lapangan.

Sementara itu, informan ke lima mengaku menerapkan etika jurnalisme warga untuk mewujudkan keinginannya menjadi jurnalis warga yang profesional layaknya seorang wartawan. Ia berusaha menjunjung nilai-nilai jurnalisme yang sesuai dengan kaidah jurnalistik dalam setiap liputannya, seperti menyajikan berita yang sesuai fakta dan bersikap netral. Ia memandang etika jurnalisme warga tak hanya mengacu pada Undang-Undang Pers saja, tetapi juga soal moralitas. Dengan menyeimbangkan kualitas beritanya dan menjaga sopan santunnya di lapangan, informan ini berharap dapat mewujudkan keinginannya untuk menjadi jurnalis warga yang profesional.

Kehormatan profesi (sebagai wartawan atau jurnalis) rupanya mempengaruhi motif mereka dalam menerapkan etika jurnalisme warga. Tingkat kesibukan profesi atau pekerjaan dalam keseharian mereka selain menjadi jurnalis warga turut mempengaruhi intensitas mengirim video untuk NETCJ serta dalam memperdalam ilmu mengenai kaidah jurnalistik. Semakin banyak profesi yang digeluti informan, maka tingkat motif menerapkan etika jurnalisme warga semakin berkurang akibat kesibukan yang mereka alami.

Dua dari lima informan hanya berfokus pada aspek moralitas saja. Aspek ini terdiri atas: menjaga sopan santun, menjaga nama baik diri dan media bersangkutan, serta agar diterima di masyarakat. Tiga informan lainnya mengutamakan dua aspek sekaligus, yaitu aspek moralitas dan kualitas dalam menerapkan etika jurnalisme warga. Ketiganya tidak hanya mengutamakan soal sopan santun saja, namun juga kualitas pada hasil liputannya. Hal ini terlihat pula pada pengamalan mereka dalam mempelajari kaidah jurnalistik yang sesuai, yakni Kode Etik Jurnalistik dan Undang-Undang Pers.

Jika disimpulkan, secara keseluruhan motif para informan menerapkan etika jurnalisme warga memiliki makna sebagai aspek moralitas dan kualitas. Dua aspek tersebut menjadi faktor yang sangat berpengaruh dalam membentuk motif mereka menerapkan etika jurnalisme warga. Pada aspek moralitas, mereka berfokus pada hal-hal yang berkaitan dengan sopan santun dan 
etika sehingga memberi kemudahan dalam proses liputan yang mereka lakukan. Sedangkan pada aspek kualitas, mereka berfokus pada hal-hal yang berkaitan dengan kualitas hasil liputan yang sesuai dalam kode etik dalam jurnalistik.

Tabel 1. Motif Menerapkan Etika Jurnalisme Warga

\begin{tabular}{|c|c|c|c|c|c|}
\hline Kesepakatan & $\begin{array}{c}\text { Informan } \\
\text { I }\end{array}$ & $\begin{array}{c}\text { Informan } \\
2\end{array}$ & $\begin{array}{c}\text { Informan } \\
2\end{array}$ & $\begin{array}{c}\text { Informan } \\
4\end{array}$ & $\begin{array}{c}\text { Informan } \\
5\end{array}$ \\
\hline Mengakui status sebagai jurnalis warga & $\sqrt{ }$ & $\sqrt{ }$ & $\sqrt{ }$ & $\sqrt{ }$ & $\sqrt{ }$ \\
\hline membuat liputan yang sesuai fakta & $\sqrt{ }$ & $\sqrt{ }$ & $\sqrt{ }$ & $\sqrt{ }$ & $\sqrt{ }$ \\
\hline menjaga nama baik media yang bersangkutan & $\sqrt{ }$ & $\sqrt{ }$ & $\sqrt{ }$ & $\sqrt{ }$ & $\sqrt{ }$ \\
\hline menolak pemberian amplop & $\sqrt{ }$ & $\sqrt{ }$ & $\sqrt{ }$ & $\sqrt{ }$ & $\sqrt{ }$ \\
\hline $\begin{array}{c}\text { tidak mengirim liputan yang sama ke media } \\
\text { lain }\end{array}$ & $\sqrt{ }$ & $\sqrt{ }$ & $\sqrt{ }$ & $\sqrt{ }$ & $\sqrt{ }$ \\
\hline
\end{tabular}

Sumber: Olahan Peneliti, 2018

\section{Pengalaman dalam Menerapkan Etika Jurnalisme Warga}

Sebagai jurnalis warga, para informan ini tentunya memiliki pengalaman tersendiri dalam menerapkan etika jurnalisme warga. Mereka memiliki pengalaman yang berbeda-beda. Dalam poin ini, pengalaman informan dibahas berdasarkan tantangan yang mereka hadapi saat menerapkan etika jurnalisme warga saat di lapangan beserta cara mereka menghadapinya.

Para informan ini memiliki berbagai tantangan yang dihadapi dalam menerapkan etika jurnalisme warga. Mereka pun memiliki caranya tersendiri untuk menghadapi tantangannya masing-masing tanpa merugikan pihak lain. Mereka tetap mengutamakan aspek kejujuran, sehingga tidak menyalahgunakan status mereka sebagai jurnalis warga ataupun mengaku sebagai wartawan dari media lain.

Untuk menggambarkan pengalaman informan secara keseluruhan, peneliti kembali menggunakan fase tindakan Schutz, yakni fase tindakan because-motive atau $\mathrm{m}$ otif sebab dan fase tindakan in-order-to motive atau motif tujuan. Berdasarkan hasil penelitian, para informan dalam penelitian ini memiliki pengalaman masa lalu (motif sebab) yang kemudian membentuk persepsi masing-masing saat memaknai pengalaman mereka dalam menerapkan etika jurnalisme warga. Beberapa tantangan yang kerap mereka temui, yakni berupa (1) gratifikasi, (2) eksistensi diri, dan (3) kesulitan akses liputan.

Tantangan pertama yang dialami adalah gratifikasi alias diberikan amplop oleh narasumber. Hal ini diakui oleh kelima informan karena mereka pernah mengalaminya saat liputan. Informan 1 misalnya, ketika diberikan amplop oleh narasumbernya, dengan tegas selalu menolak dan mengembalikannya. Hal ini dikarenakan baginya kehadiran amplop tersebut sebagai beban tersendiri jika liputannya tidak tayang, sehingga ia selalu menolaknya. Informan ini menyadari, seperti halnya wartawan profesional, seorang jurnalis warga tidak boleh menerima amplop, karena baginya hal ini akan membuat nama jurnalis warga di Solo menjadi buruk. Selain dikhawatirkan akan mencoreng nama baiknya, ia juga khawatir amplop akan mempengaruhi objektivitas liputannya.

Informan kedua mengaku pernah diberikan amplop oleh narasumbernya. Namun, ia menolaknya karena menganggap kehadiran amplop seperti beban dan khawatir narasumber akan terus me nanyakan kapan liputannya ditayangkan. Bagi informan dua, jika pemberian dari narasumber masih berupa makanan atau suvenir masih dalam tahap wajar untuk diterima. Meski demikian, ia tetap berusaha untuk membuat liputan yang berimbang dan tidak terpengaruh dengan narasumbernya. Namun, informan dua ini selalu menolak pemberian berupa amplop 
DOI: $10.24198 /$ jkj.v3i2.22167

dari narasumbernya.

Demikian pula dengan informan ketiga, juga mengaku pernah diberi amplop oleh narasumbernya. Karena merasa bertentangan dengan hati, ia langsung menolak dan mengembalikannya. Baginya, pemberian dari narasumber berupa amplop menjadi beban tersendiri karena terkesan mengikat dengan hasil liputannya yang belum tentu tayang. Maka dari itu, informan ketiga juga menolak amplop. Lain halnya jika pemberian dari narasumber berupa barang, informan ketiga ini biasanya tetap menerimanya karena takut menyinggung perasaan mereka ketika ia menolaknya. Setidaknya, ia tetap berusaha untuk membuat liputan yang sesuai fakta dan tidak terpengaruh oleh pihak mana pun. Hingga saat ini, ia mengaku belum pernah diberikan amplop lagi oleh narasumbernya sejak kejadian dua tahun yang lalu itu.

Informan keempat juga mengaku kerap diberikan amplop atau suvenir saat liputan. Namun, ia selalu menolak apa pun pemberian dari narasumbernya karena menganggapnya sebagai beban di hatinya jika liputannya tidak bisa tayang. Berbekal pengetahuannya dari Kode Etik Jurnalistik dan Undang-Undang Pers, ia mengaku tidak menerima bentuk gratifikasi apa pun di lapangan. Demikian pula dengan informan ke lima, ia mengaku selalu menolak amplop karena menganggap sebagai beban jika liputannya tidak tayang. Tak hanya itu, ia juga sangat menghindari cap sebagai 'wartawan bodrex' yang dianggap akan mencoreng nama baik jurnalis warga Solo lainnya dan dikhawatirkan mempengaruhi hasil liputannya.

Pengalaman seluruh informan dalam menerima amplop ini dapat dikategorikan sebagai motif sebab. Namun, sebelum memperoleh pengalaman langsung disodori amplop, para jurnalis warga ini sudah menyadari bahwa seorang jurnalis kemungkinan akan mendapatkan pengalaman tersebut. Semua informan juga menyadari bahwa amplop adalah hal terlarang bagi jurnalis. Pengalaman ini kemudian membentuk kesadaran tentang nilai-nilai ketidakpantasan mengenai amplop. Pengetahuan tentang profesionalisme kerja wartawan, kode etik dan peraturan perundang-undangan yang menaungi kerja wartawan, serta resiko yang mungkin timbul jika menerima amplop kemudian melengkapi kesadaran tersebut. Pada gilirannya aspek pengalaman dan pengetahuan ini kemudian membangun in order to motive atau motif tujuan untuk menolak amplop.

Tantangan yang dihadapi kedua, yakni perihal eksistensi diri. Informan satu, tiga, empat dan lima terkadang mendapati diri mereka dianggap sebagai wartawan oleh narasumber atau masyarakat setempat. Informan pertama mengaku sejak awal selalu memperkenalkan dirinya sebagai jurnalis warga terlebih dahulu. Hal ini ia lakukan untuk menghindari kesalahpahaman agar tidak merugikan pihak mana pun, terutama wartawan kontributor NET. Namun, ia terkadang masih menemukan narasumbernya yang salah paham dengan menganggapnya sebagai wartawan.

Informan ketiga juga mengaku selalu memperkenalkan dirinya terlebih dahulu sebagai jurnalis warga dan tidak pernah mengaku-ngaku sebagai wartawan kepada narasumbernya. Namun, terkadang ada narasumber atau masyarakat setempat yang menganggapnya sebagai wartawan. Berdasarkan pengalaman tersebut, because-motive yang dialaminya adalah dianggap sebagai wartawan. Pengalaman sama juga diperoleh informan lima, yang terkadang dianggap sebagai wartawan oleh narasumbernya. Padahal sebelumnya, ia selalu memperkenalkan diri sebagai jurnalis warga dan tidak pernah mengaku sebagai wartawan. Namun, ia kerap menerima label sebagai wartawan oleh masyarakat karena videonya sering tayang di NET.

Tantangan terakhir yang juga termasuk because motive adalah pengalaman menghadapi kesulitan akses liputan. Hal ini diungkapkan oleh informan empat dan lima. Terutama dalam liputan acara yang bersifat resmi, informan empat biasanya diminta untuk menunjukkan kartu 
pers atau tanda pengenal. Persoalan ini tentu membuatnya kesulitan untuk mendapat akses liputan. Serupa dengan informan empat, informan lima juga merasa izin liputan acara resmi menghambatnya. Biasanya ia ditanyai dari mana asalnya sebelum bisa masuk. Ia pun kerap merasa kesulitan dengan persoalan izin tersebut.

Konsep interaksi simbolik berasumsi bahwa manusia dapat mengerti berbagai hal dengan belajar dari pengalaman. Persepsi seseorang selalu diterjemahkan dalam simbol-simbol. Secara sosial, seseorang dapat melakukan tindakan kepada dirinya sendiri. Dengan kata lain, seseorang dapat menjadikan dirinya sebagai objek tindakannya sendiri, melalui "definisi" yang dibuat bersama orang lain (Kuswarno, 2009: 114). Konsep ini sangat erat kaitannya dengan konsep tentang diri (self), yakni persepsi yang relatif stabil yang dipercaya orang lain mengenai dirinya sendiri.

Pengalaman para informan dalam menerapkan etika jurnalisme warga melalui tantangan yang dihadapinya merupakan konsep diri yang terbentuk dari hasil interaksi informan dengan orang-orang di sekitarnya. Berdasarkan temuan lapangan, diketahui bahwa kelima informan memiliki makna yang sama terhadap tantangan yang pertama, yakni diberikan amplop oleh narasumber. Kelima informan menganggap amplop sebagai beban tersendiri jika liputan mereka tidak tayang, sehingga mereka selalu menolaknya. Setelah ditelusuri, kelima informan tersebut menggunakan kata "beban" dalam memaknai gratifikasi dari narasumber. Pemilihan kata yang mereka sampaikan tersebut tentu bukan tanpa alasan.

Informan pertama dan kedua menggambarkan betapa beratnya beban amplop dari narasumber jika diterima oleh jurnalis warga, karena narasumber nantinya menjadi terus berharap dan menanyakan kapan liputannya ditayangkan. Serupa dengan informan kedua, informan ketiga juga menganggap amplop sebagai beban karena terkesan seperti "mengikat" dengan hasil liputannya dengan narasumber. Begitu pula dengan informan keempat dan kelima yang menganggap amplop sebagai beban di hati, sehingga mereka pun selalu menolak dan mengembalikannya.

Terhadap tantangan kedua, yakni perihal eksistensi diri karena dianggap sebagai wartawan, tiga orang informan mengaku memaknai jurnalis warga pada dasarnya memiliki beberapa kesamaan sebagai jurnalis atau wartawan. "Label" media yang mewadahi program jurnalisme warga mereka, yakni NET, secara tidak langsung memperkuat makna pada informan untuk memaknai jurnalis warga sebagai bagian dari lingkungan kejurnalistikan atau kewartawanan.

Di sisi lain, meski sering dianggap sebagai wartawan, status sebagai jurnalis warga membuat para informan tidak memiliki ID card atau kartu pers, padahal kartu pers sangat berguna untuk dapat menembus acara yang bersifat resmi atau formal. Meski tantangan ini menjadi hambatan, salah seorang informan mengaku tidak pernah menyalahgunakan statusnya sebagai jurnalis warga atau mengaku-ngaku sebagai wartawan. Untuk menghadapinya, salah seorang informan mengaku biasanya ia mengambil sudut pandang pemberitaan dari sisi lainnya atau melakukan PTC (Piece to Camera). Sementara informan lain berupaya mencari cara lain dengan meminta bantuan teman agar bisa menembus akses liputan tersebut. Seorang informan menceritakan pengalamannya meliput pernikahan Kahiyang-Bobby dengan meminta bantuan teman yang berasal dari organisasi masyarakat setempat untuk dibuatkan surat izin hingga akhirnya ia bisa masuk dan meliput momentum tersebut.

Secara keseluruhan, pengalaman para informan menerapkan etika jurnalisme warga memiliki makna sebagai aspek moralitas dan kualitas. Dua aspek tersebut menjadi pelindung dari tantangan yang mereka hadapi. Pada aspek moralitas, mereka berfokus pada tantangan yang berkaitan dengan sopan santun dan etika. Sedangkan pada aspek kualitas, mereka berfokus pada tantangan yang berkaitan dengan kualitas hasil liputan yang sesuai dalam kode etik dalam 
jurnalistik. Dengan hadirnya kedua aspek tersebut, pemaknaan terhadap etika jurnalisme warga menjadi lebih seimbang.

Tabel 2. Pengalaman Menerapkan Etika Jurnalisme Warga

\begin{tabular}{|l|l|c|c|c|c|c|}
\hline \multicolumn{2}{|c|}{ Pengalaman } & Informan 1 & Informan 2 & Informan 3 & Informan 4 & $\begin{array}{c}\text { Informan } \\
5\end{array}$ \\
\hline \multirow{5}{*}{ Gratifikasi } & Berupa uang & $\sqrt{ }$ & $\sqrt{ }$ & $\sqrt{ }$ & $\sqrt{ }$ & $\sqrt{ }$ \\
\cline { 2 - 7 } & $\begin{array}{l}\text { Berupa souvenir/ } \\
\text { kupon }\end{array}$ & - & $\sqrt{ }$ & $\sqrt{ }$ & $\sqrt{ }$ & $\sqrt{ }$ \\
\cline { 2 - 6 } & $\begin{array}{l}\text { Berupa makan gratis } \\
\text { di kedai/restoran }\end{array}$ & - & - & - & $\sqrt{ }$ & $\sqrt{ }$ \\
\hline Eksistensi diri & $\begin{array}{l}\text { narasumber } \\
\text { menganggp jurnalis } \\
\text { warga sebagai } \\
\text { wartawan }\end{array}$ & $\sqrt{ }$ & - & $\sqrt{ }$ & - & $\sqrt{ }$ \\
\hline $\begin{array}{l}\text { Kesulitan akses } \\
\text { liputan }\end{array}$ & $\begin{array}{l}\text { Ditanya soal ID Card } \\
\text { (kartu pers) saat } \\
\text { liputan acara resmi }\end{array}$ & - & - & - & $\sqrt{ }$ & $\sqrt{ }$ \\
\hline
\end{tabular}

Sumber: Olahan Peneliti, 2018

\section{KESEPAKATAN MENGENAI ETIKA JURNALISME WARGA}

Sama hal dengan jurnalisme pada umumnya, jurnalisme warga juga memerlukan etika jurnalisme. Hingga saat ini memang belum ada aturan tertulis secara resmi mengenai etika jurnalisme warga. Namun, setidaknya ada prinsip-prinsip mengenai etika jurnalisme yang bisa dijadikan landasan oleh jurnalis warga, misalnya Kode Etik Jurnalistik dan Undang-Undang Pers.

Pihak redaksi NETCJ pun mengakui hingga saat ini belum ada Kode Etik Jurnalistik khusus bagi jurnalis warga. Maka dari itu, perihal landasan kode etik maupun peraturan peliputan, dikembalikan kepada masing-masing media jurnalisme warga. Seperti NETCJ, yang membuat aturan kode etik bagi anggota jurnalis warganya dalam situsnya, http://netcj.co.id/ term_of_service.

Dengan dibuatnya aturan ini oleh pihak redaksi NETCJ, diharapkan dapat menjadi pedoman bagi anggotanya dalam membuat konten jurnalisme warga. Jika ada pelanggaran yang dilakukan oleh anggotanya, pihak redaksi langsung memberi peringatan pertama secara lisan kepada pelanggar. Namun, jika selanjutnya mengulangi kesalahan yang sama, peringatan kembali diberikan kepada pelanggar secara tertulis lewat e-mail. Untuk pelanggaran yang ketiga kalinya, redaksi terpaksa memblokir akun pelanggar sehingga ia tidak bisa lagi mengirim video liputan ke NETCJ dan mengikuti seluruh rangkaian kegiatan NETCJ.

Perihal cara-cara yang ditempuh oleh jurnalis warga NETCJ saat liputan, redaksi NETCJ memberi kebebasan kepada mereka selama tidak merugikan pihak NET maupun NETCJ. Segala bentuk perjanjian antara jurnalis warga dan narasumber menjadi kesepakatan dan tanggung jawab masing-masing individu. Hal ini juga berkaitan dengan soal pemberian amplop dari narasumber dan "akses lain" yang digunakan salah satu informan dalam menembus wilayah liputan acara resmi.

Dalam upaya menerapkan etika jurnalisme warga, para informan ini menggunakan landasan-landasan tertentu dalam kaidah jurnalistik sebagai pedoman. Hal ini dikarenakan hingga saat ini belum ada aturan tertulis mengenai etika jurnalisme warga. Maka dari itu, beberapa dari para informan ini menggunakan beberapa landasan yang sesuai dengan etika 
jurnalisme pada umumnya, di antaranya Kode Etik Jurnalistik dan Undang-Undang Pers.

Seperti informan pertama dan keempat, mereka menggunakan Kode Etik Jurnalistik sebagai pedoman mereka dalam menerapkan etika jurnalisme warga. Selain itu, informan keempat dan kelima menggunakan Undang-Undang Pers sebagai pedomannya. Sedangkan informan kedua dan ketiga mengaku tidak memiliki pedoman secara khusus dalam menerapkan etika jurnalisme warga, melainkan hanya menggunakan asas moralitas sebagai landasannya.

Kesepakatan para informan mengenai etika jurnalisme warga merupakan konsep diri yang terbentuk dari hasil interaksi informan dengan orang-orang di sekitarnya. Berdasarkan pengalaman dan pengetahuan masing-masing, kelima informan ini memiliki beberapa makna yang sama mengenai kesepakatan mengenai etika jurnalisme warga yang mereka bentuk bersama secara langsung maupun tidak langsung.

Berdasarkan hasil penelitian, diketahui para informan dalam penelitian ini memiliki kesepakatan mengenai etika jurnalisme warga yang berkaitan dengan moralitas dan kualitas. Di antaranya terdapat: (1) mengakui status sebagai jurnalis warga, (2) membuat liputan yang sesuai fakta, (3) menjaga nama baik media yang bersangkutan, (4) menolak pemberian amplop dari narasumber, (5) tidak mengirim liputan yang sama ke media lain.

Para informan memiliki pemaknaannya sendiri-sendiri dalam memaknai kesepakatan ini, salah satunya lewat penggunaan kata yang mereka sampaikan. Salah seorang informan selalu mengajak rekan-rekannya untuk memperkenalkan diri sebagai jurnalis warga dan tidak mengaku sebagai wartawan kepada narasumber. Hal ini dilakukan untuk mencegah, terutama mencegah kesalahpahaman pada kalangan wartawan kontributor NET. Hal serupa diakui oleh dua orang informan lainnya. Informan kelima mengaku sangat menjaga statusnya sebagai jurnalis warga agar tidak dianggap sebagai "wartawan bodrex" atau wartawan tanpa media oleh narasumbernya maupun orang lain.

Kesepakatan untuk mengakui status sebagai jurnalis warga ini juga berkaitan dengan Kode Etik Jurnalistik Pasal 2, yakni Wartawan Indonesia menempuh cara-cara yang profesional dalam melaksanakan tugas jurnalistik. Dalam poin penafsiran dijelaskan cara profesional tersebut dilakukan dengan menunjukkan identitas diri kepada narasumber. Sama halnya pada jurnalisme warga, seorang jurnalis warga juga harus menunjukkan profesionalitasnya melalui pengakuan identitas dirinya.

Kesepakatan kedua, yakni membuat liputan yang sesuai fakta. Sebagian besar informan menyepakati hal ini. Para informan tersebut memaknai kesepakatan ini melalui penggunaan kata yang mereka sampaikan. Salah seorang informan menjelaskan bahwa ia menggambarkan liputan yang sesuai fakta sebagai bentuk tanggungjawabnya sebagai jurnalis warga. Ia juga ingin menjaga kualitas beritanya sehingga ia harus membuat berita yang sesuai dengan fakta. Informan lainnya mengaku ingin membuat berita yang sesuai fakta, akurat, dan lengkap informasinya sehingga dapat dipercaya. Informan keempat ingin membuat berita sesuai fakta agar hasil liputannya dapat diapresiasi oleh NET maupun khalayak. Sedangkan informan kelima ingin membuat liputan yang sesuai fakta karena ingin menjunjung nilai-nilai jurnalisme yang sesuai untuk mewujudkan diri sebagai jurnalis warga yang profesional.

Membuat liputan sesuai fakta berkaitan dengan Kode Etik Jurnalistik Pasal 1, 2, dan 3. Inti dari ketiga pasal tersebut membahas bahwa wartawan harus memberitakan peristiwa yang sesuai fakta tanpa campur tangan dari pihak lain serta dengan jelas mencantumkan sumbernya. Selain itu, penting pula untuk menguji informasi dengan check and recheck atau menguji kebenaran informasi yang diperoleh berkali-kali. Pada jurnalisme warga, hal ini juga harus dilakukan sehingga jurnalis warga dapat menjaga kualitas berita yang dibuat.

Kesepakatan ketiga adalah menjaga nama baik media yang bersangkutan. Salah seorang 
informan memaknai kesepakatan ini melalui penggunaan kata yang ia sampaikan, yakni "membawa nama baik media". Dengan membawa nama baik media yang dibawanya, ia dapat menjaga nama baiknya pula sebagai jurnalis warga. Membawa nama baik dilakukan seluruh informan antara lain dengan mengakui bahwa statusnya bukan sebagai wartawan, melainkan jurnalis warga. Dengan memperkenalkan diri sebagai jurnalis warga, para informan ini mengaku turut menjaga nama baik media yang dibawa, yakni NET dan program NETCJ. Pengakuan ini muncul atas kesadaran akan tanggung jawab sebagai individu jurnalis warga. Di sisi lain, redaksi NETCJ juga membuat kesepakatan dengan para jurnalis warga bahwa jurnalis warga diperbolehkan menggunakan akses apa pun asal tidak mengatasnamakan sebagai perwakilan NET.

Kesepakatan keempat, yakni menolak pemberian amplop dari narasumber. Kelima informan menyepakati hal ini, namun dengan pemaknaannya sendiri-sendiri. Seluruh informan mengakui pemberian amplop dari nara sumber sebagai sebuah 'beban'. Salah seorang informan menggambarkan betapa beratnya beban dari amplop. Ia menganggap amplop seperti uang haram dan membuat narasumber akan menanyakan terus kapan liputannya tayang. Maka dari itu, ia selalu menolak pemberian amplop dari narasumbernya. Informan lain menganggap amplop sebagai 'beban' karena terkesan seperti 'mengikat' dengan hasil liputannya dengan narasumber.

Kesepakatan mengenai menolak pemberian amplop dari narasumber ini juga berkaitan Kode Etik Jurnalistik Pasal 6, yakni Wartawan Indonesia tidak menyalahgunakan profesi dan tidak menerima suap. Dalam poin penafsirannya, dijelaskan bahwa suap adalah pemberian dalam bentuk uang, benda, atau fasilitas dari pihak lain yang mempengaruhi independensi. Beberapa informan mengaku masih menerima pemberian berupa barang atau suvenir agar tidak menyinggung narasumber, terkecuali berupa amplop atau uang. Hal ini disepakati asal tidak mempengaruhi independensi mereka dalam membuat berita.

Kesepakatan terakhir adalah tidak mengirim liputan yang sama ke media lain. Hal ini disampaikan oleh salah seorang informan. Meski hanya memaparkan seorang diri, namun pernyataannya tersebut dibenarkan oleh aturan yang dibuat oleh NETCJ. Bagi sang informan, jurnalis warga memang tidak terikat dengan satu media saja. Mereka bebas mengirimkan karyanya ke media mana pun, namun tidak dengan mengirimkan gambar atau liputan yang sama ke televisi atau media lain. Secara tidak langsung, informan lainnya juga menyetujui hal ini karena merupakan salah satu aturan tertulis dalam kode etik yang dibuat oleh NETCJ.

Beberapa poin dari kesepakatan yang disampaikan oleh kelima informan ini, sebenarnya juga telah dipaparkan secara tertulis oleh NETCJ yang dapat diakses di http://netcj.co.id/term of_service. Menurut redaksi NETCJ, terkait kode etik dan peraturan peliputan yang dipakai di medianya, sebagian besar berpedoman pada Kode Etik Jurnalistik yang berlaku saat ini. Beberapa poin aturan NETCJ yang memiliki kesamaan dan berkaitan dengan pembahasan ini, yakni: (1) anggota (member) tidak dibenarkan dan tidak berhak menyebut dirinya sebagai wartawan atau jurnalis NET, (2) NETCJ atau NET dibebaskan dari segala tuntutan dan pertanggungjawaban atas segala tindakan terkait pencarian berita atau pembuatan video, (3) anggota bertanggungjawab secara pribadi dan penuh atas konten video yang telah diunggah, (4) setiap video yang telah diunggah dan dipublikasikan melalui NETCJ merupakan milik NET, (5) video yang telah diunggah dan dipublikasikan tidak dapat diunduh kembali baik seluruhnya maupun sebagian, video secara absolut milik NET.

Dengan demikian, secara keseluruhan kesepakatan para informan mengenai etika jurnalisme warga memiliki makna sebagai aspek moralitas dan kualitas. Dua aspek tersebut menjadi faktor yang sangat berpengaruh dalam membentuk kesepakatan mereka. Pada aspek 
moralitas, mereka berfokus pada hal-hal yang berkaitan dengan sopan santun dan etika sehingga memberi kemudahan dalam proses liputan yang mereka lakukan. Sedangkan pada aspek kualitas, mereka berfokus pada hal-hal yang berkaitan dengan kualitas hasil liputan yang sesuai dalam kode etik dalam jurnalistik. Dengan hadirnya kedua aspek tersebut, pemaknaan terhadap etika jurnalisme warga menjadi lebih seimbang.

Tabel 3. Kesepakatan Mengenai Etika Jurnalisme Warga

\begin{tabular}{|c|c|c|c|c|c|}
\hline Kesepakatan & $\begin{array}{c}\text { Informan } \\
1\end{array}$ & $\begin{array}{c}\text { Informan } \\
2\end{array}$ & $\begin{array}{c}\text { Informan } \\
2\end{array}$ & $\begin{array}{c}\text { Informan } \\
4\end{array}$ & $\begin{array}{c}\text { Informan } \\
5\end{array}$ \\
\hline Mengakui status sebagai jurnalis warga & $\sqrt{ }$ & $\sqrt{ }$ & $\sqrt{ }$ & $\sqrt{ }$ & $\sqrt{ }$ \\
\hline membuat liputan yang sesuai fakta & $\sqrt{ }$ & $\sqrt{ }$ & $\sqrt{ }$ & $\sqrt{ }$ & $\sqrt{ }$ \\
\hline menjaga nama baik media yang bersangkutan & $\sqrt{ }$ & $\sqrt{ }$ & $\sqrt{ }$ & $\sqrt{ }$ & $\sqrt{ }$ \\
\hline menolak pemberian amplop & $\sqrt{ }$ & $\sqrt{ }$ & $\sqrt{ }$ & $\sqrt{ }$ & $\sqrt{ }$ \\
\hline $\begin{array}{c}\text { tidak mengirim liputan yang sama ke media } \\
\text { lain }\end{array}$ & $\sqrt{ }$ & $\sqrt{ }$ & $\sqrt{ }$ & $\sqrt{ }$ & $\sqrt{ }$ \\
\hline
\end{tabular}

Sumber: Olahan Peneliti, 2018

\section{SIMPULAN}

Jurnalis warga NETCJ di wilayah Solo memaknai etika jurnalisme warga sebagai aspek moralitas dan kualitas. Dua aspek tersebut menjadi faktor yang sangat berpengaruh dalam membentuk motif, pengalaman, dan kesepakatan mereka dalam menerapkan etika jurnalisme warga. Aspek moralitas berkaitan dengan sopan santun dan etika sehingga dapat memudahkan proses liputan, sedangkan aspek kualitas menyangkut upaya jurnalis warga untuk membuat konten liputan yang berkualitas. Motif sebab umumnya didorong oleh penerapan nilai-nilai etika dan moral sebagai kunci sukses dalam pergaulan sosial di masyarakat. Nilai-nilai ini juga kemudian diterapkan dalam aktivitas jurnalisme warga melalui penerapan kode etik jurnalistik dan regulasi lain yang relevan dalam kejurnalistikan. Adapun motif tujuan (in-order-to motive) para jurnalis warga adalah keinginan agar menghasilkan liputan yang berkualitas dan dapat diterima di masyarakat; untuk menjaga nama baik diri serta media yang bersangkutan; dan mewujudkan keinginan menjadi jurnalis warga yang profesional.

Interaksi jurnalis warga dengan orang-orang disekitar menghasilkan konsep diri (self) dalam menerapkan etika jurnalisme. Tantangan tersebut juga dimaknai sebagai aspek moralitas dan kualitas, dalam bentuk gratifikasi, eksistensi diri, dan kesulitan akses liputan. Dalam menghadapi tantangan tersebut, jurnalis warga memiliki cara masing-masing untuk menghadapinya, seperti menolak pemberian amplop, selalu memperkenalkan diri sebagai jurnalis warga, membuat angle liputan lain, hingga meminta bantuan dari pihak lain. Tantangan ini juga dihadapi dengan membuat kesepakatan diantara jurnalis warga NETCJ di wilayah Solo untuk berpedoman pada Kode Etik Jurnalistik, Undang-Undang Pers, serta kode etik yang dibuat oleh NETCJ. Kesepakatan-kesepakatan tersebut di antaranya mengakui status sebagai jurnalis warga, membuat liputan yang sesuai fakta, menjaga nama baik media yang bersangkutan, menolak pemberian amplop dari narasumber, dan tidak mengirim liputan yang sama ke media lain. Bentuk-bentuk kesepakatan ini memberi kontribusi dalam membangun konsep diri (self) sebagai seorang jurnalis warga. 
136 | Kajian Jurnalisme

Volume 03 Nomor 02 Tahun 2020

DOI: $10.24198 /$ jkj.v3i2.22167

\section{DAFTAR PUSTAKA}

Cresswell, J. (2010). Research Design, Pendekatan Kualitatif, Kuantitatif, dan Mixed. Yogyakarta: Pustaka Pelajar.

Dan, B., \& Iii, S. (2017). Konferensi nasional. (December), 358-367. https://doi.org/10.25008/ pknk.v1il.101

Eddyono, A. S., HT, F., \& Irawanto, B. (2019). Menyoroti Jurnalisme Warga: Lintasan Sejarah, Konflik Kepentingan, dan Keterkaitannya dengan Jurnalisme Profesional. Jurnal Kajian Jurnalisme, 3(1), 1. https://doi.org/10.24198/jkj.v3i1.21762

Iqbal, M., \& Sjafirah, N. A. (2019). Makna Jurnalisme Warga Bagi Jurnalis Warga Netcj.Co.Id. Jurnal Kajian Jurnalisme, 3(1). https://doi.org/10.24198/kj.v3i1.21364

Kuswarno, E. (2009). Metodologi Penelitian Komunikasi Fenomenologi: Konsepsi, Pedoman, dan Contoh Penelitiannya. Widya Padjadjaran.

Markham, T. (2009). Global Practices of Citizen Journalism : Democratizing and Collectivist or Regulatory and Individualist? 59th Political Studies Association Annual Conference Challenges for Democracy in a Global Era Panel : The democratic / political potential in the use of new media technologies Abstract:

Moleong, L. J. (2017). Metodologi Penelitian Kualitatif (Edisi Revisi). In PT. Remaja Rosda Karya (p. 424).

Mulyana, D. (2010). Metodologi Penelitian Kualitatif. Bandung: PT Remaja Rosdakarya.

Nugraha, P. (2012). Citizen Journalism: Pandangan, Pemahaman, dan Pengalaman. Jakarta: PT Kompas Media Nusantara.

Santana, S. (2017). Jurnalisme Kontemporer. Jakarta: Yayasan Pustaka Obor Indonesia.

Sugiono. (2007). Memahami Penelitian Kualitatif. Bandung: Alfabeta.

Sukartik, D. (2016). Peran Jurnalisme Warga Dalam Mengakomodir Aspirasi Masyarakat. Jurnal Risalah, 27(1), 10-16. https://doi.org/10.24014/jdr.v27i1.2508

Widodo, Y. (2017). Menyoal Etika Jurnalisme Kontemporer: Belajar dari OhmyNews. Jurnal ASPIKOM, 1(1), 41. https://doi.org/10.24329/aspikom.v1i1.7 